\title{
A Review on an Experimental Analysis Work on Strength of Thirsty Concrete with Different Types of Coarse Aggregate
}

\author{
Mr. Harishankar Patel ${ }^{1}$, Mrs. K Divya ${ }^{2}$, Ms. Anisha Mire ${ }^{3}$ \\ ${ }^{1}$ Research Scholar, ${ }^{2}$ Assistant Professor, ${ }^{3}$ Assistant Professor \\ ${ }^{1,2,3}$ Department of Civil Engineering \\ RSR Rungta College of Engineering Technology, Bhilai, India
}

DOI: 10.46335/IJIES.2020.5.7.2

\begin{abstract}
To overcome the problem of water logging due to impermeability of floors and pavement, the pervious concrete is the best solution that increases the better understanding of linkage between microstructure, transport properties and durability will assist in mix proportion and design. There are two major issue while working with Pervious concrete. First is the strength of pervious concrete is very weak due to absence of fine aggregate and other is the high demand for natural construction material. This paper, Represent about the materials, properties, construction \& Design Mix of pervious concrete and provide a details about the limitations and future scope of the usage of pervious concrete in India. The experimental work deals with the effect of different types of coarse aggregate in strength.
\end{abstract}

A total numbers of 45 specimens were cast with $20 \mathrm{~mm}$ size \& other 45 specimen cast with $12 \mathrm{~mm}$ size aggregate of angular, flaky, rounded, broken marbles and recycled aggregate cured and tested for compressive strength. The specimens were cast without adding any fine aggregate with the mix proportion 1: 4.38 (cement: aggregate) and by adding $10 \%$ fine aggregate with the mix proportion 1:0.438:3.95 (cement: sand :aggregate). This research is total of two different mixes of various shape and materials were used such as without and with fine aggregates, two different coarse aggregates, of size $12 \mathrm{~mm}$ and $20 \mathrm{~mm}$. The experiment has been done in this project has considered 7 days, 14days and 28 days compressive strength of pervious concrete. The mix M2 with river sand as Normal River sand and crusher stone sand and $12 \mathrm{~mm}$ coarse aggregate has shown superior performance in terms of higher compressive strength than mixM1.
Keywords- Angular, Flaky, Rounded, Broken Marble and Recycled Aggregate, Pervious Concrete, Sand.

\section{I- INTRODUCTION}

E which are situated near the sea like Chennai, Kolkata and Mumbai if there are heavy rainfalls happens during high tide, then the tide causes the water to wash back into the city, and it is not absorbed by the surface that leading to water logging. A lack of state-of-the-art rain forecasting system could have been a factor in water logging earlier but India recently updated its weather tech and the blame for water logging now squarely lies on the unpreparedness of the state municipal corporations.

Adding to manmade problems are natural reasons for this problem getting worse each year. As the health of countries worsens, the health of its states \& cities worsen too. The absorbing of Water such as wastelands, saltpans, wetlands and mangroves of our country are shrinking due to reestablishments of land uses for development - this leaves more and more storm water to be dealt with by civic authorities who are already burdened with a multitude of problems.

Pervious concrete is known as the special type of concrete that have high voids which increases it's permeability applied for concrete work \& flatwork applications that permits water from weather action like 
precipitation, raining and other sources to travel through it, which minimizing the runoff from the effected site and can recharging ground water levels. Typically thirsty concrete has no fine aggregate or has little fine aggregate and has just appropriate cementious paste to overcoat the coarse aggregate particles while conserving the interrelativity of the pores.

Background History of Pervious Concrete:- Pervious concrete was first applied in 1800 in Europe as pavement material for surface covering and structure of load bearing. The initial use of pervious concrete was made in the Britain in near to 1850 with the construction of two houses of residential and a seawall. The pervious concrete is applied initially in 1852 (Ghafoori and Dutta). Although not a new technology, pervious concrete is achieving renewed interest in the America, partly cause of FCWL(Federal Clean Water Legislation). The (USEPA)Environmental Protection Agency's Phase II requires the Final Rule to operators of all municipalities in urban areas to develop, execute, and impose a program to minimize pollution particles in post-construction runoff from redevelopment and new growth projects that outcome in disturbance of land of greater than or equal to 1 acre.

Pervious concrete is a highly porous type of concrete which is light in weight and it is obtained by reducing, replacing or withdrawing the fine aggregate from the conventional concrete. The ingrained properties of the thirsty concrete is low cost due to less cement content, low bulk density, low conductivity of temperature and drying shrinkage, less segregation and high porous movement of water. Due to the availability of large voids, this concrete is applied as a permeable material. Pervious concrete does not represent the sufficient strength of compression due to pervious material with conventional shape and size though it need to prevent storm water runoff from initiating flood and downstream abrasion. Pervious concrete is basically used in parking areas wherethe traffic is light, pedestrian walkways, foot-path, and greenhouses. Pervious concrete is an improved implementation for sustainable construction of structure.

This experimental work is carried out to enhance the strength of compression of thirsty concrete with alternate shape and size of aggregate with little percentage of fine aggregate say $10 \%$.

\section{II- RECYCLED AGGREGATE AS AN ALTERNATIVE COURSE AGGREGATE}

The aim of sustainable design is to minimize the environmental effect of a constructed structure throughout whole period of life. The composite material is a basic construction material in construction work in the whole world. Due to developments in the activities of demolition and construction worldwide, the waste of concrete materials after the demolition of any infrastructure is known as a waste material which is not applicable for any purpose which is totally economical loss of the country because for the construction process the natural resource are consume day by day. The waste material like debris is also termed as the major issues for municipal parties to throw out at particular location. Recycled aggregate is most usual application in whole world that the lots of material (like rubber, plastic, wood, paper, concrete etc), are being reused to conserve the natural resources and environments. Concrete is known as expensive material but in present day's the waste of this concrete is being applied as a filler material for landfill instead of reusing \&recycling the concrete waste as a Recycled Concrete Aggregate (RCA) to apply for the purpose of construction.

\section{III- RESEARCH FINDINGS}

The following are the previous research review based on analysis, experimental analysis\& formation of thirsty concrete properties. In this chapter we are trying to focus on the experimental analysis of the effects of various sizes \& shapes of aggregate used in pervious concrete making process $\&$ their effects on the compressive strength of concrete cubes.

Jing Yang et al. in 2003 published a paper in which he showed that, a special concrete pavement material known as pervious concrete is introduced for roadway as aggregate size decreases compressive strength enhances while absorption of water decreases. Super plasticizer and Silica Fume can be used to prepare high strength concrete and excellent water absorbing concrete. he tested a number of samples for flexural strength, split tensile strength impact resistance thawing and freezing capacity and compressive strength. Void percentage determines compressive strength and permeability of pervious concrete. Quality of cement must be maintained according to aggregate's smaller size to increase compressive strength. He conclude that we can increase the strength of pervious concrete by using SF, SP and other organic polymer.. 
Kevern et al. in 2006 a paper in which he showed that, a wide variety of construction practices are currently used for pervious concrete placement, yet the effects on hardened material properties are not known. An overview of placement methods is provided and slab samples were placed in the laboratory using different field-based methods. He concluded on his paper that, The density versus porosity relationship is linear for a particular mixture. Fewer passes with a heavy roller produces more uniform compaction, while more passes with a lighter roller densities the surface layer.

Suleiman et al. in 2006 published a paper in which study was conducted to Fresh and hardened concrete properties he explained that, Samples using the same mixture proportions compacted at two different energies, low and high, had very different properties. Strength decreased and permeability and porosity increased. It was expected that the low compaction samples would experience more rapid freeze-thaw deterioration.

Wang et al. in 2006 showed a comprehensive study of mixture proportioning had not been performed which used freeze-thaw durability as a primary criteria. A variety of aggregate types, gradations, and sizes were investigated along with binder amount and admixture dosages. The author concluded that, approximately $7 \%$ fine aggregate by weight of coarse aggregate provided significant increases to strength and durability. Acceptable mixtures should have permeability greater than $0.1 \mathrm{~cm} / \mathrm{s}$, compressive strength greater than $20 \mathrm{MPa}$, and less than $5 \%$ mass loss at 300 cycles using the ASTM C666A method.

Maguesvari et al in 2013 says that due to impermeability of impervious pavement surface and urbanization Ground water table reduces. Thirsty concrete is an environment friendly material and identified for its capability of draining water. Its area of application consist lower traffic roads, Pedestrian ways, shoulders and parking areas Void in thirsty concrete decreases with decrease in aggregate size and with increasing proportion of fine aggregate replacing coarse aggregate with decrease in size of coarse aggregate compressive strength of concrete increases. Also replacing percentage of coarse aggregate with fine aggregate increases compressive strength. This is due to increase in contact area. Flexural strength And split tensile strength are increase with increase in percentage of fine aggregate.
Permeability decreases with decrease in aggregate size and increase in fine aggregate percentage. This analysis adorn number of angularity, which effect the behavior and properties of porous concrete with aggregates of coarse and fine sizes. There be, the effect of number of angularity on the value of abrasion of thirsty concrete couldn't be established.

S. Rajesh Kumar et al in $\mathbf{2 0 1 5}$ published a paper that deals with the comparative study of the various mix design of pervious concrete made up with and without fine aggregate material. His experimental work is based on various mix design of pervious concrete. He has used total seven different mixes such as with and without fine aggregates, and different coarse aggregates of two types of size $20 \mathrm{~mm}$ and 12 $\mathrm{mm}$ and with fine aggregate as Normal River sand and crushed stone sand. He concluded that The mix M4 with normal sand and $12 \mathrm{~mm}$ size coarse aggregate has shown best performance in terms of greater void ratio than other mixes. It gives $83 \%$ extra compressive strength $72 \%$ extra tensile strength and $51 \%$ minimum void ratio as compare to M1 mix.

Vikram et al in 2015 published a paper in which study was conducted to examine the experimental performance of pores pervious concrete with help of ad mixtures he find that the pervious concrete has low costs of installation. And it is a structure with open-cell and does not absorb thermal radiation of heat In this analysis on pervious concrete behavior various mix proportions are prepared by replacing cement with silica fume which is replace by $6 \%$ of the weight of cement and addition of super plasticizers by $0.13 \%$ and $0.25 \%$ with size variation of aggregates. The ratio of water-cement was maintained up to 0.34 . the various parameter like flexural strength, split tensile strength, workability and compressive strength test at 7,28 \& 56 days and bonding strength at same days have been experimentally analyzed. By the experimental results of his study it is concluded that the addition of replacement material decreased the strength of thirsty concrete. The mix proportions with aggregates size $(4.75 \mathrm{~mm}$ to $10 \mathrm{~mm})$ gives higher strength when compared to mixes with aggregates size $(10 \mathrm{~mm}$ to $20 \mathrm{~mm})$ and $(4.75 \mathrm{~mm}$ to $20 \mathrm{~mm})$ respectively.

Prof. Shilpi S. Bhuinyan et al in 2019 presented a paper that deals with the study of the various materials with different type, shapes and sizes are used to get better results. The infiltration 


\section{Impact Factor Value 5.856 \\ e-ISSN: 2456-3463 \\ International Journal of Innovations in Engineering and Science, Vol 5, No.7, 2020 $w w w . i j i e s . n e t$}

rate, abrasion resistance and durability of the materials used are also good. And an experimental study evaluating strength and permeability characteristics of a pervious concrete mix design is presented. The experimental work included compressive strength tests(at 7 and 28 days, and infiltration rate test(at 28 days) on clean specimens .Resulting that Its void content ranges from 18 to $35 \%$ with compressive strengths of 2.74 to $27.56 \mathrm{MPa}$.

Summary of Literature review:- The above are the previous research review based on the experimental study of pervious concrete .In this paper we discuss about the material, property, mix design, casting and construction of pervious concrete by using different aggregates from various origins and of different shapes and size. In this project our objective is to enhance the compressive strength of pervious concrete by using different shaped coarse aggregates and replacing aggregate with broken marble and recycled aggregate. In these study to know that effect of recycled aggregates and its mix proportions to be gain higher compressive strength, and improved properties of pervious concrete.

\section{IV-CONCLUSIONS}

The main point of this review is on production of concrete using waste material as a key point of increasing compressive strength by using various shaped aggregate with \& without fine aggregate and using recycled aggregate waste material (Broken Marble) in replacing fast depleting conventional aggregate sources as construction material and thereby finding the solution for better compressive strength and appropriate binding capacity for social and environmental issues. At present, the increasing expense of structure development materials is the factor of extraordinary concern. The test in making an appropriate proportion of cement concrete for thirsty concrete design. Introducing new mix proportion of cement: fine aggregate: aggregates for designing thirsty concrete. From the experimental results and discussions of above- researches on various shaped aggregate, and waste material like recycled aggregate and broken marble, the recycled aggregate has potential as conventional aggregate in thirsty concrete. Likewise, utilizing the recycled aggregate as alternative in cement can decrease the material costing as it is a waste product. Recycled aggregate exhibits comparable resistance against- impact and abrasion, with respect to quarry aggregate. There is no compelling reason to treat the recycled aggregate before use as an aggregate aside from water absorption.

\section{REFERENCE}

[1] Jing Yang, Guoliang Jiang. - Experimental study on properties of pervious concrete pavement materialsl, Cement and Concrete Research 33 (2003) 381-386 ISSN 0008-8846.

[2] Kevern, J.T. Mix Design Determination for Freeze-thaw Resistant Portland Cement Pervious Concrete, Master's Thesis, Ames, IA: Iowa State University, 2006.

[3] Kevern, J. T., Wang, K., Suleiman, M. T., and Schaefer, V. R. "Pervious Concrete Construction: Methods and Quality Control." CD-ROM. Proceedings of the 2006 NRMCA Concrete Technology Forum - Focus on Pervious Concrete, Nashville, TN, 2006.

[4] Schaefer, V.R., Wang, K., Sulieman, M.T., and Kevern, J. Mix Design Development for Pervious Concrete in Cold Weather Climates. A Report from the National Concrete Pavement Technology Center (CP Tech Center), Ames, IA: Iowa State University, 2006.

[5] P.C.Bala murugan, R.Avinash. - Experimental Probe on Thirsty Concrete Using Recycled Aggregate (2019) ISSN: 2349-6002

[6] Prof. Shilpi S. Bhuinyan, Shreyance Luniya. -An Experimental Study on Strength and Properties of Thirsty Concrete (2019) ISSN: 2349-6002

[7] S. Rajesh Kumar. -Characteristic Study on Pervious Concrete (2015) ISSN:0976 - 6308

[8] Vima Velayudhan Ithikkat and Dipu V S, “Analytical Studies On Concrete Filled Steel Tubes” International Journal of Civil Engineering \& Technology (IJCIET), Volume 5, Issue 12, 2014, pp. 99 - 106, ISSN Print: 0976 - 6308, ISSN Online: 0976 - 6316.

[9] IS 456-2000, "Indian Code of Practice for Plain and Reinforced concrete" Bureau of Indian Standards, Fourth revision, New Delhi

[10] IS 516: 1959 methods of tests for strength of concrete (RA1991).

[11] IS: 383-1970, "Specification for coarse and fine aggregates from Natural sources for concrete"' Bureau of Indian Standards, ninth reprint, New Delhi.

[12] IS: 383 (1970), 'Code of practice for the Specification for coarse and fine aggregate from natural source for concrete', Bureau of Indian Standards, New Delhi.

[13] IS: 456 (2000), 'Code of practice for Plain and Reinforcement concrete', Bureau of Indian Standards, New Delhi.

[14] IS: 10262 (2009). "Concrete Mix Proportioning Guidelines”, Bureau of Indian Standards, New Delhi. 